\title{
Phagotrophy by a plastidic haptophyte, Prymnesium patelliferum
}

\author{
Urban Tillmann* \\ Forschungs- und Technologiezentrum Westküste, Universität Kiel, D-25761 Büsum, Germany
}

\begin{abstract}
Observations and photographs of the previously unsuspected ingestion capacity of the phytoflagellate Prymnesium patelliferum are presented. P. patelliferum took up prey cells of different sizes by an elongated, U-shaped pseudopodium formed at the posterior part of the cells. While feeding, aggregates of several $P$. patelliferum cells were formed in which their pseudopodia come in close contact. Motile prey cells were immobilised or probably killed before ingestion, but not all protistan species of ingestible size were immobilised or attacked. It is suggested that $P$. patelliferum may secrete a toxin that serves as a killing agent for prey organisms.
\end{abstract}

KEY WORDS: Prymnesium patelliferum - Mixotrophy $\cdot$ Phagotrophy Haptophyta

\section{INTRODUCTION}

Phagotrophy by photosynthetic flagellates is a wellknown phenomenon described in the phycological literature as early as the late 19th century. This process has recently been 'rediscovered' and its potential ecological significance addressed as part of the rapid evolution in microbial food web ecology. Many higher algal taxa have species with both photosynthetic and phagotrophic nutrition (mixotrophy). This is most common in the dinoflagellates (Schnepf \& Elbrächter 1992), chrysophytes (Sanders \& Porter 1988) and prymnesiophytes (Green 1991, Jones et al. 1994). In the latter group, descriptions of mixotrophic species are nearly exclusively restricted to the genus Chrysochromulina. In only 1 case has phagotrophy been recorded in the coccolithophorids (Parke \& Adams 1960).

Prymnesium Conrad, the type genus of Prymnesiophyceae, has a number of toxic bloom-forming species separated morphologically only by the fine-structural details of body scales (Green et al. 1982) and is well known to cause extensive fish kills in brackish ponds in Israel (Reich \& Aschner 1947), Denmark (Otterstrøm \& Steemann Nielsen 1940), Germany (Lenz 1933, Hickel

\footnotetext{
•E-mail: tillmann@ftz-west.uni-kiel.de
}

1976, Dietrich \& Hesse 1990), Bulgaria (Valkanov 1964) and Norwegian coastal waters (Kaardtvedt et al. 1991). Because of its economic importance as an ichthyotoxin-producing genus, Prymnesium is an oftencultivated and well-studied organism. Nevertheless, for a long time, the only documentation of phagotrophy within this genus was an anecdotal description by Conrad (1941), who described particle ingestion by pseudopodia in amoeboid cells of $P$. saltans Massart. Little detail was given in that report and confirmatory observations were lacking (Green 1991). However, Nygaard \& Tobiesen (1993) recently showed that $P$. parvum, among several other species of flagellates, was able to ingest bacteria both in the field and in the laboratory. In the present study, I show that particle ingestion by Prymnesium is not restricted to bacteria but that at least $P$. patelliferum is able to incorporate different sized particles, sometimes even larger than itself.

\section{MATERIALS AND METHODS}

In 1992, Prymnesium patelliferum was isolated from a brackish pond near Büsum, northern Germany. From this isolate, unialgal cultures were obtained by the dilution technique and were grown in natural seawater 
( $\mathrm{S}=28 \%$ ) enriched with nutrients (Guillard \& Ryther 1962). Species determination, based on TEM examination of the scales, was carried out by J. Green (Plymouth Marine Laboratories, UK). Cultures were maintained at $20^{\circ} \mathrm{C}$ under natural light in the laboratory. To study phagotrophy, senescent cultures were mixed with different species of other protists (Table 1). Live observations were made using an inverted microscope (Zeiss Axiovert 35) equipped with a Nikon photomicrography system and documented with a Panasonic video system. From video tapes, single frames were printed by a Sony video-printer.

\section{RESULTS}

In exponentially growing cultures, Prymnesium patelliferum is elongate and slender with 2 chloroplasts covering the whole cell in the longitudinal axis. In dense and senescent cultures, the cell shape changes to a more rounded form. The chloroplasts are smaller and the posterior part of the cell is often filled with a large body of reserve metabolite, probably chrysolaminarin. The cells are often filled with small oil droplets. In addition, cells with a large brownish pellet in the posterior occurred and sometimes excretion of this body by the cells was observed. These cellular features, with hindsight, possibly resulted from cannibalism, i.e. the brown bodies strongly resembled 'faecal pellets', suggesting the occurrence of phagotrophy.

After mixing senescent Prymnesium patelliferum cultures with other protist cultures, some $P$. patelliferum cells showed a swollen and transparent posterior, which afterwards formed an elongated U-shaped

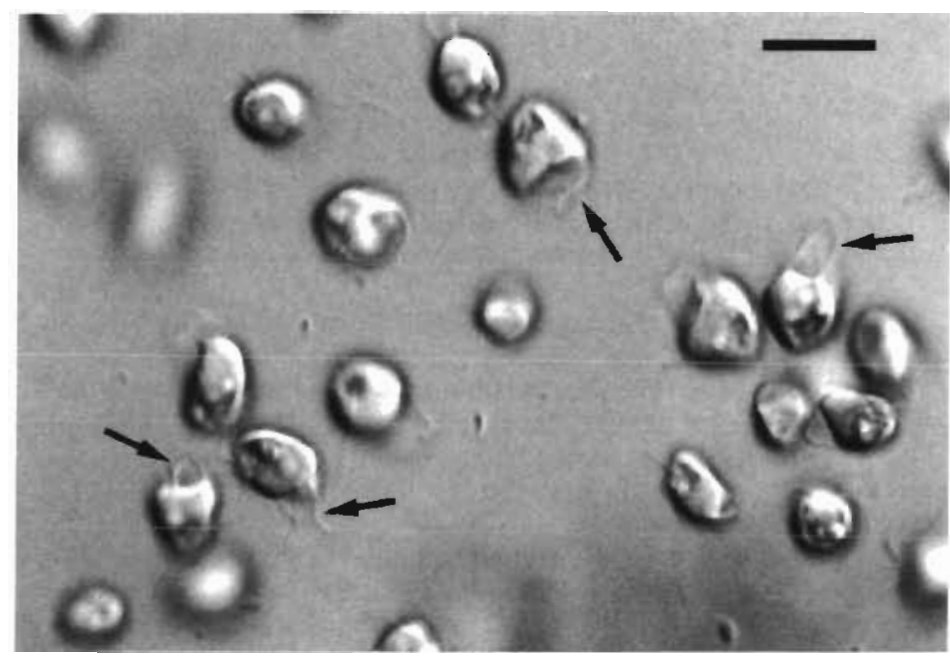

Fig. 1. Prymnesium patelliferum forming elongated pseudopodia (arrows) at the posterior part of the cell prior to feeding activity. Scale bar $=10 \mu \mathrm{m}$
Table 1 List of species tested for their suitability as prey for Prymnesium patelliferum

\begin{tabular}{|lcc|}
\hline Species & $\begin{array}{c}\text { Diameter } \\
(\mu \mathrm{m})\end{array}$ & $\begin{array}{c}\text { Ingestion } \\
\text { observed }\end{array}$ \\
\hline Unknown Chlorococcales & $5-10$ & + \\
Dunaliella sp. & 7 & + \\
Cryptomonas sp. & 10 & - \\
Skeletonema costatum (Greville) Cleve & 10 & - \\
Thalassiosira rotula Meunier & 30 & - \\
Oxyrihis marina Dujardin & 30 & + \\
Gyrodinium sp. & 45 & + \\
Unknown amoeba & 12 & + \\
& & \\
\hline
\end{tabular}

pseudopodium (Fig. 1). Presumably, the formation of the pseudopodium is chemically stimulated and not triggered by direct contact with the prey, because it was often observed in cells not surrounded by algal food. If $P$, patelliferum with a pseudopodium encountered a food particle, the particle was completely enclosed by the pseudopodium and taken up into a food vacuole located at the posterior of the cell within about 1 min (Figs. 2 \& 3).

In cultures of motile protists mixed with Prymnesium patelliferum, a varying number of potential prey cells lost their motility. This effect was not due to observation handling (e.g. microscopic illumination) as determined by prey-alone control cultures under the microscope. For example, Fig. 4a shows the immobilised and rounded form of an amoeba. This species can then easily be ingested by $P$. patelliferum, as shown in Fig. 4b, c.

Single prey cells were often attacked by several Prymnesium patelliferum cells simultaneously. Sometimes, when multiple $P$. patelliferum encountered a single prey, the membranous pseudopodia of $P$. patelliferum cells appeared to merge to enclose the prey between them. This process is illustrated with a series of sequential images taken from video (Fig. 5). Resulting feeding aggregates of the 2-cell type are most common (Figs. 4c \& 6a-e), but 3 or more $P$. patelliferum cells may be involved (Fig. 6f). $P$. patelliferum also aggregated around relatively large prey. Both the heterotrophic dinoflagellate Oxyrrhis marina (Fig. 7) and the phototrophic Gyrodinium sp. (Fig. 8) were attacked. The predator cells formed a more or less complete coat over the prey. In such cases, the shape of a single $P$. patelliferum cell could be extremely deformed

Differences in suitability of protistan prey for Prymnesium patelliferum were observed. While the Chlorococcales and an amoeba were ingested (Figs. 2 to 4 ), the similarly sized Cryptomonas sp. and Skeletonema costatum 

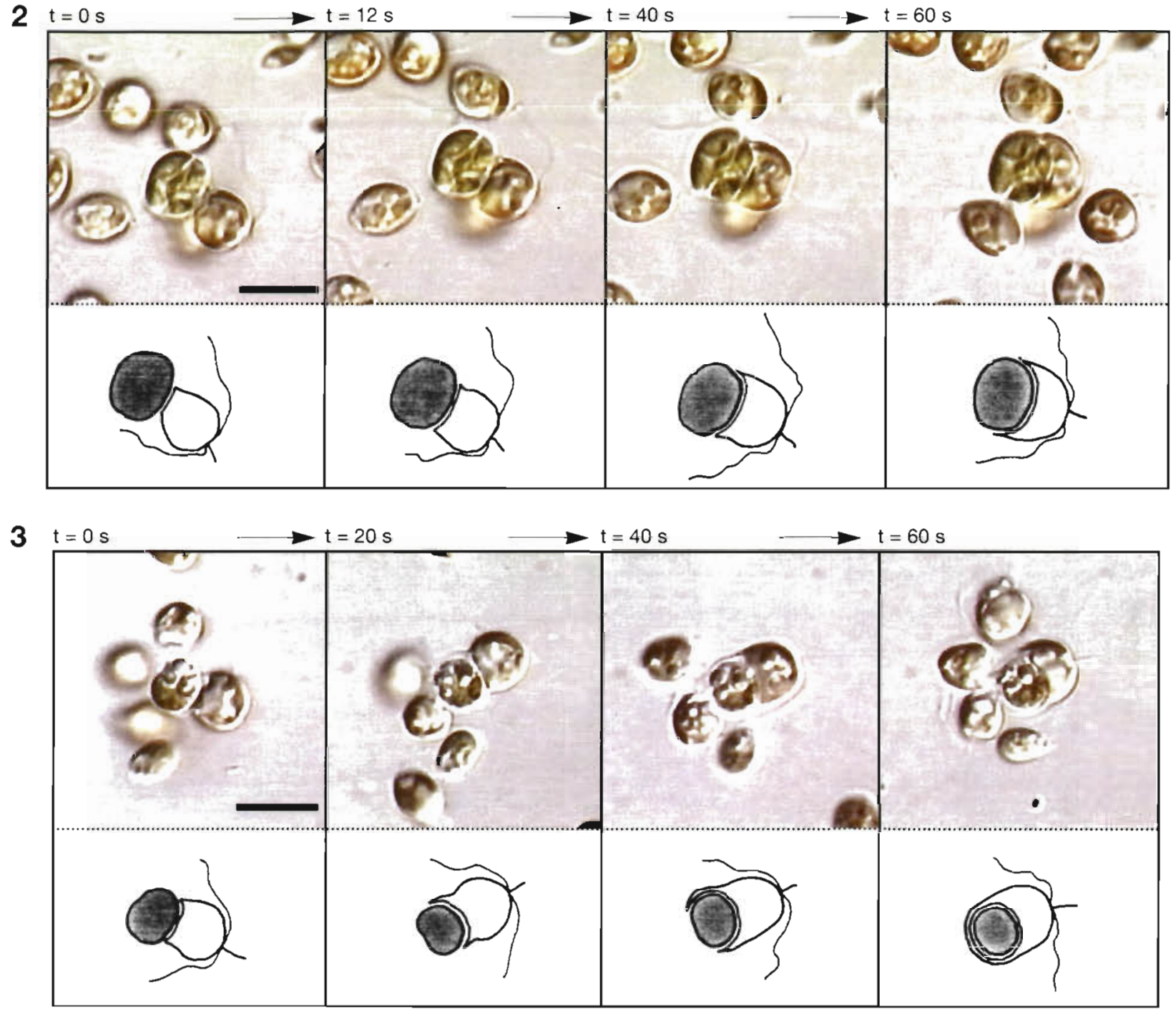

Figs. 2 \& 3. Time course of prey ingestion by Prymnesium patelliferum. The drawings in the lower part give a schematic simplified view of pseudopod action. Scale bars $=10 \mu \mathrm{m}$. Fig. 2. P. patelliferum ingesting an unidentified chlorococcalean alga. Fig. 3. P. patelliferum ingesting Dunaliella sp.

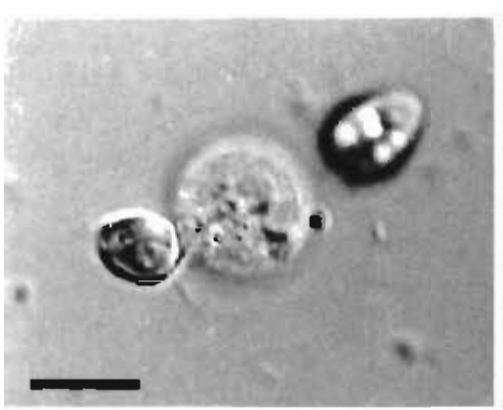

b

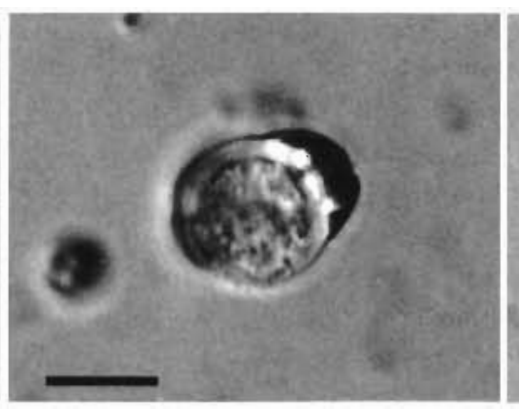

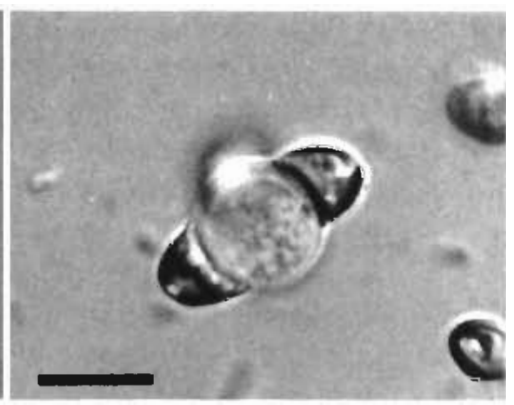

Fig. 4. Prymnesium patelliferum ingesting an amoeba. (a) After addition to a $P$. patelliferum culture, the amoebae lost their motility and became rounded. (b) After ingestion, the amoeba can be seen in a large food vacuole. (c) Two cells in close connection with the food between them. Scale bars $=10 \mu \mathrm{m}$ 

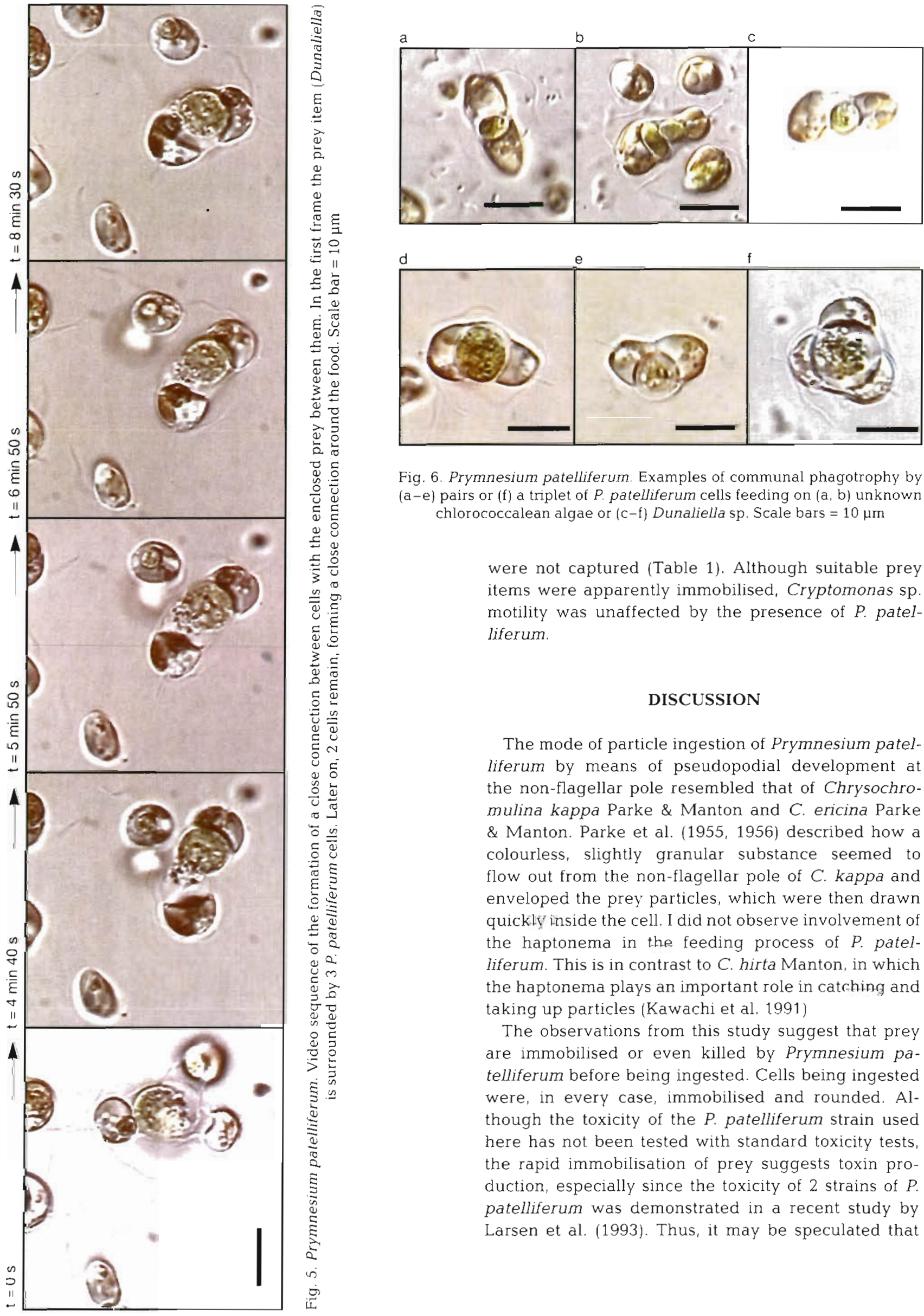

Fig. 6. Prymnesium patelliferum. Examples of communal phagotrophy by $(\bar{a}-e)$ pairs or $(\mathrm{f})$ a triplet of $P$. patelliferum cells feeding on $(\mathrm{a}, \mathrm{b})$ unknown chlorococcalean algae or (c-f) Dunaliella sp. Scale bars $=10 \mu \mathrm{m}$

were not captured (Table 1). Although suitable prey items were apparently immobilised, Cryptomonas sp. motility was unaffected by the presence of $P$. patelliferum.

\section{DISCUSSION}

The mode of particle ingestion of Prymnesium patelliferum by means of pseudopodial development at the non-flagellar pole resembled that of Chrysochromulina kappa Parke \& Manton and C. ericina Parke \& Manton. Parke et al. $(1955,1956)$ described how a colourless, slightly granular substance seemed to flow out from the non-flagellar pole of C. kappa and enveloped the prey particles, which were then drawn quickly inside the cell. I did not observe involvement of the haptonema in the feeding process of $P$. patelliferum. This is in contrast to C. hirta Manton, in which the haptonema plays an important role in catching and taking up particles (Kawachi et al. 1991)

The observations from this study suggest that prey are immobilised or even killed by Prymnesium patelliferum before being ingested. Cells being ingested were, in every case, immobilised and rounded. Although the toxicity of the $P$. patelliferum strain used here has not been tested with standard toxicity tests, the rapid immobilisation of prey suggests toxin production, especially since the toxicity of 2 strains of $P$. patelliferum was demonstrated in a recent study by Larsen et al. (1993). Thus, it may be speculated that 


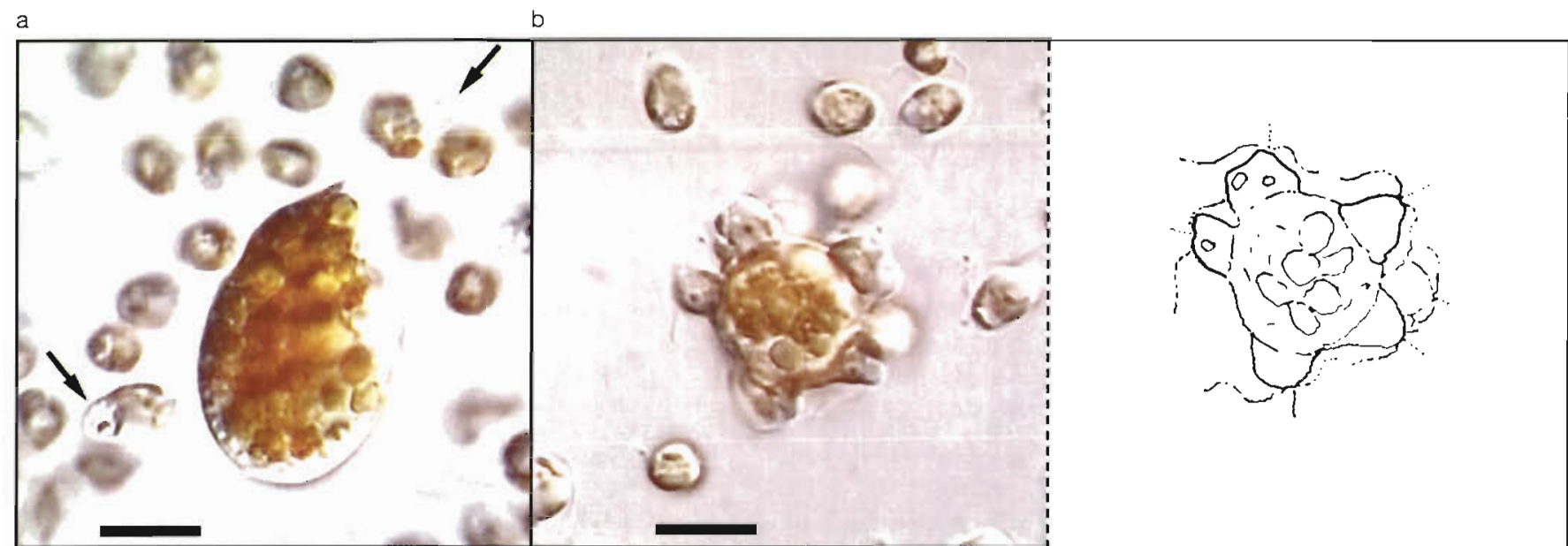

Fig. 7. Prymnesium patelliferum attacking a cell of the heterotrophic dinoflagellate Oxyrrhis marina. Scale bars $=10 \mu \mathrm{m}$. (a) The dinoflagellate cell, coloured due to ingested Dunaliella cells, is completely rounded off. Nearby, P. patelliferum cells 'ready to feed' with the typical swollen hyaline posterior part (arrows) can be seen. (b) Several P. patelliferum cells have settled on the surface of a smaller individual $O$. marina

Prymnesium toxin may be used to kill potential prey organisms prior to ingestion. Toxins of haptophytes are well known to affect organisms of their own size class, like amoeba, flagellates and ciliates (Valkanov 1964) and bacteria, phytoplankton and zooplankton (Moestrup 1994). Estep \& McIntyre (1989) hypothesised that toxin released by Chrysochromulina spp. simply punches holes in the cell membrane of other organisms. According to this hypothesis of auxotrophy following induced osmosis (dasmotrophy), the prey is not killed, but an outflow of nutrients is induced, which Chrysochromulina spp. can take up and absorb. The advantage to species producing toxins is still under discussion.
Not all potential prey were ingested by Prymnesium patelliferum. Cryptomonas sp. retained their motility in the presence of $P$. patelliferum and thus are probably insensitive to $P$. patelliferum toxin. The failure of $P$. patelliferum to ingest the 2 tested diatom species may be due to chain formation (Skeletonema costatum), spines (Thalassiosira rotula) or in general to surface properties of silica shells. Handling problems seem unlikely, however, since $P$. patelliferum could ingest other species in the same size range of the diatoms (Table 1). Field studies have demonstrated that diatoms are not affected by either $P$. parvum (Otterstrøm \& Steemann Nielsen 1940) or Chrysochromulina leadbeateri Estep et al. (Johnsen \& Lomsland 1991).

a

b

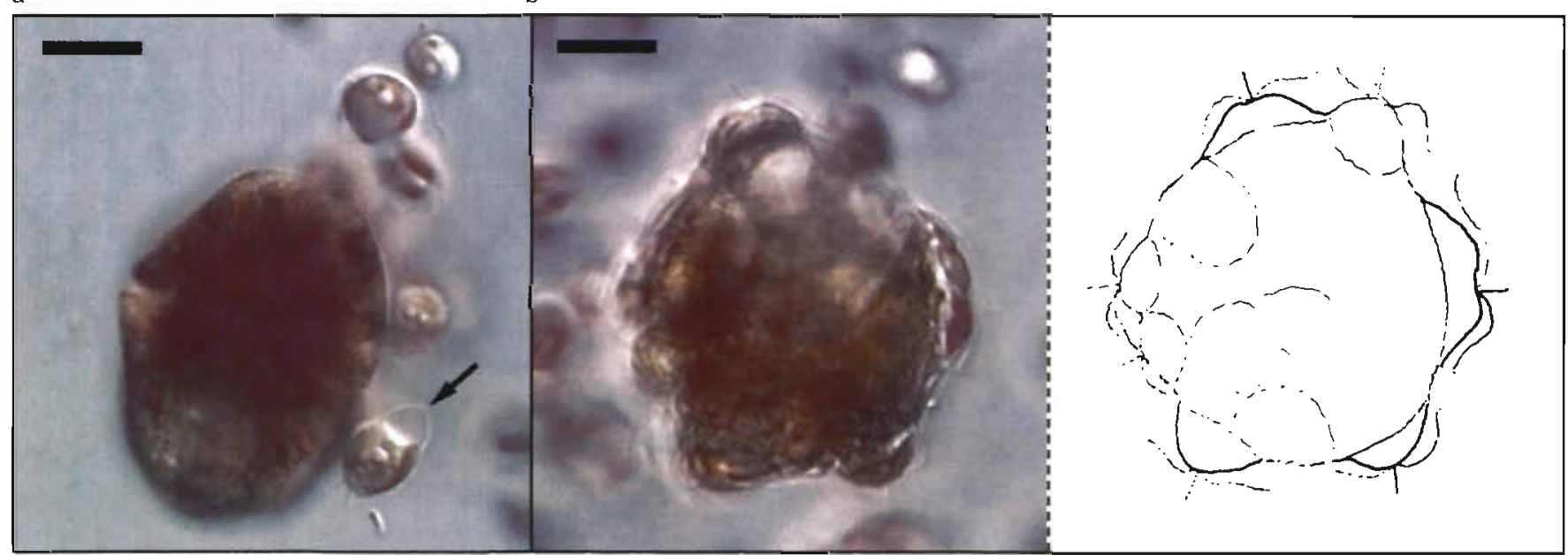

Fig. 8. Pymnesium patelliferum attacking the autotrophic dinoflagellate Gyrodinium sp. Scale bars = 10 Hm. (a) lmumediately after addition to the $P$. patelliferum culture, the dinoflagellate loses its motility, but the cell shape is still recognisable. Nearby, $P$. patelliferum cells 'ready to feed' with the typical swollen hyaline posterior part (arrow) can be seen. (b) In a later stage, several $P$. patelliferum cells form a dense layer around Gyrodinium sp. P patelliferum cells are extremely deformed 
When more than 1 Prymnesium patelliferum cell attacked a prey item, the membrane material of the predatory cells often appeared to fuse and form a common food vacuole (e.g. Fig. 6). Such feeding communities with concomitant cell fusion and a subsequent formation of common food vacuoles are known from the freshwater heliozoan Actinophrys sol (Patterson \& Hausmann 1981). For $P$. patelliferum a cell fusion process remains speculative, since it was not possible to identify a continuous membrane unambiguously in the light microscope. Refined cytological techniques are needed to clarify this problem. However, formation of a fused common food vacuole will not be required in the case of pinocytosis of leaked dissolved nutrients or for phagocytosis of small cell particles which may eventually be released after disruption of the prey's cell wall.

It is unknown whether the formation of cell aggregates and feeding by Prymnesium patelliferum cells occur under natural conditions. The current observations of phagotrophy by senescent-stage cells suggest that the phenomenon may be most common towards the end of Prymnesium blooms. Further detailed microscopical inspection of natural Prymnesium blooms for uncommon cell aggregates will give more insight into these interesting questions.

Acknowledgements. This study was supported by a grant from the German Ministry for Research and Technology (03F0130) within the framework of the TRANSWATT project. Thanks to Anette Mayer-Brinkmann for her excellent technical assistance and to John Green for species determination. I greatly appreciate valuable comments on the manuscript from John Green (Plymouth Marine Laboratories), Malte Elbrächter (Biologische Anstalt Helgoland) and Franciscus Colijn (Forschungs- und Technologiezentrum Büsum).

\section{LITERATURE CITED}

Conrad W (1941) Sur les Chrysomonadines à trois fouets. Aperçu synoptique. Bull Mus R d'Hist Nat Belgique 17:1-16

Dietrich W, Hesse KJ (1990) Local fish kill in a pond at the German North Sea coast associated with a mass development of Prymnesium sp. Meeresforsch 33:104-106

Estep KW, MacIntyre F (1989) Taxonomy, life cycle, distribution and dasmotrophy of Chrysochromulina: a theory accounting for scales, haptonema, muciferous bodies and toxicity. Mar Ecol Prog Ser 57:11-21

Green JC (1991) Phagotrophy in prymnesiophyte flagellates. In: Patterson DJ, Larson J (eds) The biology of free-living heterotrophic flagellates. The Systematics Association, Spec Vol No. 45. Clarendon Press, Oxford, p 401-414

Green JC, Hibberd DJ, Pienaar RN (1982) The taxonomy of Prymnesium (Prymnesiophyceae) including a description of a new cosmopolitan species, $P$. patellifera sp. nov., and further observation on P. parvum N. Carter. Br Phycol J $17: 363-382$
Guillard RRL, Ryther JH (1962) Studies of marine planktonic diatoms. I. Cyclotella nana Hustedt and Detonula Confervacea (Cleve) Gran. Can J Microbiol 8:229-239

Hickel B (1976) Fischsterben in einem Karpfentelch bei einer Massenentwicklung des toxischen Phytoflagellaten Prymnesium parvum Carter (Haptophyceae). Arch FischWiss $27(2): 143-148$

Johnsen TM, Lomsland ER (1991) Growth experiments with Chrysochromulina leadbeateri. In: Rey F (ed) The Chrysochromulina leadbeateri bloom in Vestfjorden, North Norway, May-June 1991. Fisken og Havet No. 3, Havforskningsinstituttet, Bergen, p 85-88

Jones HLJ, Leadbeater BSC, Green JC (1994) Mixotrophy in haptophytes. In: Green JC, Leadbeater BSC (eds) The haptophyte algae. The Systematics Association, Spec Vol No. 51. Clarendon Press, Oxford, p 247-263

Kaardtvedt S, Johnsen TM, Aksnes DL, Lie U (1991) Occurrence of the toxic phytoflagellate Prymnesium parvum and associated fish mortality in a Norwegian fjord system. Can J Fish Aquat Sci 48:2316-2323

Kawachi M, Inouye I, Maeda O, Chihara M (1991) The haptonema as a food-capturing device: observations on Chrysochromulina hirta (Prymnesiophyceae). Phycologia 30(6) $563-573$

Larsen A, Eikrem W, Paasche E (1993) Growth and toxicity in Prymnesium patelliferum (Prymnesiophyceae) isolated from Norwegian waters. Can J Bot 71:1357-1362

Lenz F (1933) Untersuchungen zur Limnologie von Strandseen. Verh Int Verein Theor Angew Limnol 6:166-177

Moestrup O (1994) Economic aspects: 'blooms', nuisance species, and toxins. In: Green JC, Leadbeater BSC (eds) The haptophyte algae. The Systematics Association, Spec Vol No. 51. Clarendon Press, Oxford, p 265-285

Nygaard K, Tobiesen A (1993) Bacterivory in algae: a survival strategy during nutrient limitation. Limnol Oceanogr 38(2): $273-279$

Otterstrøm CV, Steemann Nielsen E (1940) Two cases of extensive mortality in fishes caused by the flagellate Prymnesium parvum. Rep Dan Biol Stn 44:1-24

Parke M, Adams I (1960) The motile (Crystallolithus hyalinus Gaarder \& Markali) and non-motile phases in the life history of Coccolithus pelagicus (Wallich) Schiller. J Mar Biol Assoc UK 39:263-274

Parke M, Manton I, Clarke B (1955) Studies on marine flagellates. II. Three new species of Chrysochromulina. J Mar Biol Assoc UK 34:579-609

Parke M, Manton I, Clarke B (1956) Studies on marine flagellates. III. Three further species of Chrysochromulina. J Mar Biol Assoc UK 35:387-414

Patterson DJ, Hausmann K (1981) Feeding by Actinophrys sol (Protista, Heliozoa): 1 Light microscopy. Microbios 31. $39-55$

Reich K, Aschner M (1947) Mass development and control of the phytoflagellate Prymnesium parvum in fish ponds in Palestine. Palest J Bot 4:14-23

Sanders RW, Porter KG (1988) Phagotrophic phytoflagellates. In: Marshall KC (ed) Advances in microbial ecology, Vol 10. Plenum, New York, p 167-192

Schnepf E, Elbrächter M (1992) Nutritional strategies in dinoflagellates. Eur J Protistol 28:3-24

Valkanov A (1964) Untersuchungen über Prymnesium parvum Carter und seine toxische Einwirkung auf Wasserorganismen. Kieler Meeresforsch 20:65-81

Submitted: October 29, 1996; Accepted: October 22, 1997

Proofs received from author(s): January 28, 1998 